\title{
Life after plague
}

\section{Richard B. Gunderman ${ }^{1}$}

Received: 20 April 2020 / Revised: 20 April 2020 / Accepted: 12 May 2020 / Published online: 30 May 2020

(C) Springer-Verlag GmbH Germany, part of Springer Nature 2020

Everything passes away — suffering, pain, blood, hunger, pestilence. The sword will pass away too, but the stars will remain when the shadows of our presence and our deeds have vanished from the Earth. There is no man who does not know that. Why, then, will we not turn our eyes toward the stars? Why?

$$
\text { - Mikhail Bulgakov, The White Guard }
$$

Inspired by Albert Camus's novel, The Plague (1947), I think now is a good time to ask some questions about the implications of pandemics for pediatric radiologists. Camus's novel opens with a description of life in Oran, an ordinary town in French Algeria inhabited by ordinary people. They are like us, or rather we are like them, dutifully showing up every day to fill in templates, sign reports, draft manuscripts, and then rush off to pick up kids from piano practice, soccer practice, or play practice.

"The truth," says The Plague's narrator, "is that everyone is bored, and devotes himself to cultivating habits." People are busy leading their routine lives, scurrying about to complete each day's tasks within what always seems an insufficient allotment of time. The workdays, meetings, and journals come and go in a steady rhythm. We are busy - as busy as a person can be - but are we truly aware and alive?

Then something strange happens. The good doctor - in Camus's novel, Dr. Rieux - encounters a dead rat in the street. And then another, and another. Soon rats are dying everywhere. They stumble out of their hiding places, as if intoxicated, and drop to the pavement, bleeding from their noses. What does the town do? It hurriedly removes the rats,

Richard B. Gunderman

rbgunder@iu.edu

1 Department of Radiology, Riley Hospital for Children, Indiana University School of Medicine, 702 North Barnhill Drive, Room 1053, Indianapolis, IN 46202, USA doing its best to restore the appearance of normalcy. But the doctor knows that something deeper is afoot.

\section{Camus and The Plague}

Albert Camus (1913-1960) was born into a hardscrabble life. Growing up on French Algeria, he never knew his father. He eventually made his way to a good school but was diagnosed with tuberculosis. Working as a journalist in Paris, he published his first well-known novel, The Stranger. When the Germans invaded France, he joined the resistance, editing an underground newspaper. In 1957, 10 years after The Plague was published, Camus was awarded the Nobel Prize for Literature.

The Plague includes many memorable characters. Dr. Rieux, the narrator, is a young physician who devotes himself to treating the plague's victims. Jean Tarrou, who seems to be vacationing in the city, soon dedicates his life to combating the disease. Raymond Rambert is a journalist who misses his wife in Paris but when presented with the chance to escape Oran, he chooses to remain. Paneloux is a priest who attempts to make sense of the plague in light of his belief in God.

The single section of The Plague that pediatric radiologists might wish most assiduously to avoid is Chapter 21, for it is here that the local magistrate's son, an innocent child, endures the worst the plague has to offer. His excruciating trial takes place in a makeshift health care facility that was a classroom, where instead of learning and growing, he is destroyed. As he is dying, Dr. Rieux and the others remain at his side, each confronted by a horrible lesson that seems to defy comprehension.

\section{Preparation for plague}

Something has been afoot for us, too. There were reports in late 2019 of a new severe acute respiratory syndrome in China, but it seemed to many that we had seen it all before. Swine flu, SARS, MERS, Ebola - how many times had the sirens sounded, only for the specter to fade? Surely this would 
be the same. Perhaps some of the elderly and those with chronic health conditions would succumb, but isn't this a seasonal toll of influenza? What's so different about this one?

Camus's story suggests that people cannot see the plague. We are, he says, wrapped up in ourselves, "humanists" who disbelieve in pestilences. He continues:

A pestilence isn't a thing made to man's measure; therefore we tell ourselves that pestilence is a mere bogy of the mind, a bad dream that will pass away. But it doesn't always pass away and, from one bad dream to another, it is men who pass away, and the humanists first of all, because they have taken no precautions.

Of course, there are different ways to be prepared for plague. One is to develop a public health infrastructure that can detect and report new cases, create containment and mitigation strategies, and ensure that plenty of personal protective equipment and ventilators are on hand. But there is another kind of preparation: namely, to prepare to see what is happening as it happens, not only on charts and graphs - in the aggregate — but in each human life.

It is instructive to revisit accounts of plagues gone by - the $14^{\text {th }}$-century Black Death in Europe, the $17^{\text {th }}$-century Great Plague in London, or the $18^{\text {th }}$-century Yellow Fever in Philadelphia. It is so easy to suppose that we are different, that our CT scanners and cell phones somehow separate us from such primitive times. But in the end, our responses are not so different from theirs - protective garb, keeping our distance, avoiding large gatherings, and quarantine.

The people of Camus's Oran are ill-prepared, not because they lack PPE, but because they are unable to love. The power of routine - showing up on time, getting the work done, and then returning the next day to do the same - has fixed their gaze on the "ground at their feet." Theirs was a plodding kind of existence, drifting through life rather than living, "like wandering shadows that could have acquired substance only by consenting to root themselves in the solid earth of their distress."

\section{When plague is past}

The real danger, Camus suggests, arises when we make the absurd assumption of immortality. Those who think every next day will be like the last develop a hardening of the heart - the mistaken notion that our academic degrees and white coats afford us some kind of immunity; that we are better than others and fit to judge them; or that we are somehow exempt from the imperative to greet each morning with gratitude and rejoice at each day's end.

The people of Oran think to themselves, "It is impossible that it should be the plague, everyone knows it has vanished from the
West." Everyone knows it, that is, "except the dead." We are, Camus urges, no less fragile than every human being who has ever lived. To be sure, our standards of living are higher and our life expectancies longer, but the specter of pandemic and the mortality it portends lie always just around the corner. It takes no more than one virus-bearing rodent, bird, or bat.

Camus sees the real problem not so much in our liability to death but our failure, in losing the thread of it, to live. Every reprieve, no matter how heroic, is always temporary. The images we pediatric radiologists behold every day are as profound a memento mori as any professional could wish for, but somehow we fail to recognize and soon we forget. To revel in our status and creature comforts, or to suppose ourselves somehow secure and immune, deprives us of the ability to see, understand, and love.

The abatement of each pandemic is a cause for rejoicing, but it is also a test. We can win a battle, but the war cannot be won, at least not if death is the enemy. As Camus's Dr. Rieux realizes, no triumph is ever definitive. The victory lies not in modulating death - whether cumulative mortality statistics or the heart-wrenching death of a single innocent child - but in witnessing what has been suffered and doing our best to keep the memory alive. The novel ends with these words:

And, indeed, as he listened to the cries of joy rising from the town, Rieux remembered that such joy is always imperiled. He knew what those jubilant crowds did not know but could have learned from books: that the plague bacillus never dies or disappears for good; that it can lie dormant for years and years in furniture and linen-chests; that it bides its time in bedrooms, cellars, trunks, and bookshelves; and that perhaps the day would come when, for the bane and the enlightening of men, it would rouse up its rats again and send them forth to die in a happy city.

We remember a pandemic so that we can be prepared. Yet we should take care, lest we confine our provisions to protocols and supplies. We must be prepared to combat the plague when it arises, but we must also provide for life in the afterplague, when it is nowhere to be seen. To fail to live in full view of the ineluctability of pandemic, Camus is saying, would deprive us of the opportunity to love, and in so doing, prevent us from really living.

\section{Compliance with ethical standards}

Conflicts of interest None

Publisher's note Springer Nature remains neutral with regard to jurisdictional claims in published maps and institutional affiliations. 